\title{
(Post)socijalizam i okoliš: promjena kulturnoga krajobraza Pridravske nizine Osijeka u posljednjih pedeset godina
}

\section{Jelena Lončar}

Prirodoslovno-matematički fakultet, Geografski odsjek, Sveučilište u Zagrebu, Hrvatska

e-mail: jloncar@geog.pmf.hr

\author{
Marin Cvitanović \\ Prirodoslovno-matematički fakultet, Geografski odsjek, Sveučilište u \\ Zagrebu, Hrvatska \\ e-mail: mcvitan@geog.pmf.hr
}

\begin{abstract}
SAŽETAK Socioekonomske i društvene promjene ostavljaju tragove i u okolišu. Izmjene radne i obrazovne strukture stanovništva te ekonomski uvjeti proizvodnje dobara indirektno mijenjaju krajobraz nestankom tradicionalnih načina obrade zemlje, intenzifikacijom poljoprivrede, širenjem gradskoga načina života u ruralne prostore ili pak napuštanjem određenih prostora i njihovoga prepuštanja sekundarnoj sukcesiji. Kao posljedica svega navedenoga činjenica je da su krajobrazi često prepušteni gubljenju identiteta, neprikladnoj sanaciji i degradaciji, a EU obvezuje uspostavu učinkovite provedbe i mjere njihove zaštite. Problematika analize promjena kulturnih krajobraza jedan je od fokusa niza interdisciplinarnih istraživanja posljednjih godina. U ovom radu analizirat ce se promjena krajobraza Pridravske nizine Osijeka u razdoblju od 1961. godine do 2011. godine na području Grada Osijeka, koji uz samo naselje Osijek obuhvaća i sljedeća naselja: Tenja, Brijest, Briješće, Višnjevac, Josipovac, Tvrđavica, Sarvaš, Klisa, Nemetin i Podravlje. U istraživanju promjene krajobraza korištene su metode daljinskih istraživanja te analize statističkih podataka. Područje Grada Osijeka prošlo je kroz značajne socijalne i ekonomske promjene tijekom promatranoga razdoblja, a direktno su se i indirektno odrazile na promjene zemljišnoga pokrova i način korištenoga zemljišta, te time i izgled kulturnoga krajobraza. Izdvojeni su elementi i procesi fizičke promjene krajobraza, a evidentirani su i socioekonomski, demografski i drugi elementi koji su uvjetovali fizičke promjene krajobraza. Dobiveni rezultati pokazuju u kolikoj su mjeri navedene promjene značajne i sveobuhvatne.
\end{abstract}

Ključne riječi: Pridravska nizina, Osijek, kulturni krajobraz, agrarni krajobraz, tranzicija. 


\section{Uvod}

Ljudi mijenjaju krajobraz u svrhu iskorištavanja resursa već tisućama godina. Arheološka istraživanja u nekim dijelovima Europe pokazala su da je čovjek značajno mijenjao vlastiti okoliš pomoću vatre još prije 8500 godina. Vatra je bila prvi snažan instrument u mijenjanju fizičkoga izgleda krajobraza, ali je istovremeno bila svojevrstan čin zaposjedanja i simboličkoga obilježavanja prostora (Simmons, 2010.). Razvojem tehnologije i porastom broja stanovnika intenzitet promjene okoliša od razdoblja lovačko-sakupljačkih društava do danas, poprimio je neviđene razmjere, kako u fizičkim promjenama okoliša, tako i u raznim kulturnim utjecajima koji su u okolišu ostavljali svoj trag, poput palimpsesta (Crang, 1998.). Iako postoje vrlo različiti intenziteti promjene okoliša, i najizoliraniji i najudaljeniji krajobrazi Zemlje pod utjecajem su čovjekovih aktivnosti putem globalne atmosferske cirkulacije, morskih struja ili globalnoga zatopljenja. S obzirom na takvu dalekosežnost ljudskih utjecaja, danas na Zemlji više i nema "prirodnih" krajobraza (McKibben, 1989.) te se umjetna dihotomija između "prirodnih" krajobraza i onih nastalih pod utjecajem čovjeka sve više napušta (Ramankutty i sur., 2002.). S izvjesnom dozom sigurnosti može se ustvrditi da je svaki krajobraz u stvari kulturni krajobraz.

Američki geograf Carl Sauer u svom kapitalnom djelu Morfologija pejzaža (1925.) definirao je kulturni krajobraz kao rezultat kulture i prirodnoga okoliša - kultura je agens promjene, prirodni okoliš je medij, a kulturni krajobraz je rezultat. Dok je krajobraz definiran svojom vizualnom, vidljivom komponentom (Claval, 2008.), pojam kulturni u ovakvom se kontekstu koristi kao sinonim za ljudski, odnosno nastao pod utjecajem čovjeka (Plumwood, 2006.). I druge definicije kulturnih krajobraza najčešce se temelje na tim dvjema komponentama - ljudskim aktivnostima i (vidljivom) okolišu. Tako Farina (2000.) definira kulturni krajobraz kao geografsko područje u kojem su veze između ljudskih aktivnosti i okoliša stvorile ekološke, socioekonomske i kulturne obrasce i mehanizme povratne sprege. Prema The Cultural Landscape Foundationu $\left(\mathrm{TCLF}^{1}\right)$, kulturni krajobraz je prostor koji sadrži kulturne i prirodne resurse, a UNESCO-Ov World Heritage Comittee ${ }^{2}$ tumači kulturni krajobraz kao područje oblikovano djelovanjem prirode i čovjeka. Sve navedene definicije sadržavaju vrlo bitno obilježje krajobraza - njegovu promjenjivost.

Pojam krajobraz počinje se koristiti u Hrvatskoj krajem devedesetih godina 20. stoljeća (Marić, Grgurević, 2007.). U Hrvatskoj su prisutni i pojmovi pejzaž i krajolik, a ponekad se kao istoznačnica koristi i termin okoliš. Navedeni termini koriste se u znanstvenom, stručnom i praktičnom radu, ovisno o struci koja se njime služi. Republika Hrvatska donijela je 3. listopada 2007. Zakon o zaštiti okoliša prema kojem se osigurava "cjelovito očuvanje kakvoće okoliša, očuvanje biološke i krajobrazne raznolikosti, racionalno korištenje prirodnih dobara i energije na najpovoljniji način za okoliš, kao osnovni uvjet zdravoga života i temelj održivog razvitka" (NN 110/07). Pojam pejzaž se kao pojam koristi puno duže, a označavao je uglavnom kategoriju

$\mathbf{1}$ The Cultural Landscape Foundation, TCLF, (http://tclf.org/)

2 UNESCO World Heritage Convention, (http://whc.unesco.org/) 
prostora s određenim estetskim kvalitetama, vrijednim vizurama koje treba štititi. Krajobraz se definira kao kompleksno područje unutar kojega se mogu definirati različite značajke: fizičke i ekološke, kulturne i povijesne, estetske, socijalne, strukturne i funkcionalne značajke (Marić, Grgurević, 2007.). Autori su se u ovom radu odlučili za termin krajobraz.

Krajobrazi su kao fizionomija materijalnoga okruženja oblikovani od (ne)materijalnih sastavnica pa ih racionalnim metodama nije moguće sagledati kao cjelinu, već ih se promatra i vrednuje kroz njihove sastavnice. Osnovne sastavnice krajobraza i njegova određenja podijeljene su u osnovne grupe: prirodne sastavnice (reljef, geološka obilježja, tlo, vegetacija i pokrov tla, klima), antropogene ili kulturne (povijesna naselja i arhitektura, sustavi komunikacija, poljodjelstvo i korištenje prostora tijekom povijesnih razdoblja, arheološki slojevi), estetske ili fizionomijsko-morfološke (mjerilo, proporcije, linije razgraničenja, dominante u krajobrazu, oblici, boje, vizure, uzorci krajobraza), te osjetilne sastavnice (duhovne, asocijativne, identitet, simboli, običaji, literatura, glazba, osjećaj prostora) (Dumbović Bilušić, Obad Šćitaroci, 2007.). Zbog njihove inherentne kompleksnosti, autori su se odlučili za selektivan pristup analizi promjene kulturnoga pejzaža s naglaskom na prirodne i antropogene sastavnice, što je detaljnije pojašnjeno u metodološkom dijelu rada.

Kao posljedica svoje kompleksnosti, kulturni krajobrazi u prošlosti su se najčešće mijenjali neplanirano. Smatra se da će u sljedećih 20 do 50 godina globalne posljedice promjene okoliša imati veći utjecaj na ekosustave, ljudsko zdravlje i kvalitetu života nego klimatske promjene (Skole, 1994.). Krajobrazi su prepušteni razvojnoj sukcesiji, gubljenju identiteta, neprikladnoj sanaciji i degradaciji, a EU obvezuje uspostavu učinkovite provedbe i mjere njihove zaštite (Andlar i sur., 2011.). Problematika analize promjena kulturnih krajobraza jedan je od fokusa niza interdisciplinarnih istraživanja posljednjih godina. Dio radova usmjeren je posebice na analizu promjene kulturnih krajobraza u razdoblju socijalizma i postsocijalističke tranzicije te kako je dominantna politika ostavljala svoj trag u prostoru. Tako su Holt-Jensen i Ragmaa (2010.) pokazali kako je tranzicija izmijenila agrarni krajobraz Estonije, gdje je dio kolektiviziranih posjeda na kvalitetnom tlu uspješno prestrukturiran u tržišnoj ekonomiji, no znatan dio posjeda je napušten i ostavljen sekundarnoj sukcesiji. Melluma (1994.) u svom radu objašnjava kako je komunističko i socijalističko upravljanje ostavilo traga na kulturnom krajobrazu Latvije, potičući urbanizaciju, meliorizaciju poljoprivrednih površina i stvaranje velikih, industrijskih farmi. Sve navedeno kao posljedicu je ostavilo polariziranu strukturu latvijskoga krajobraza gdje su s jedne strane krajobrazi pod jakim antropogenim utjecajem, a s druge strane, krajobrazi s vrlo slabim antropogenim utjecajem koji se vraćaju u prijašnja stanja. Što se tiče istraživanja u Hrvatskoj, Fuerst-Bjeliš i sur. (2011.) istraživali su promjene okoliša Dalmatinske zagore od 18. stoljeća i općenito o promjenama u prostoru Triplex Confiniuma (Fuerst-Bjeliš, Zupanc, 2007.). Krištofić (2010.) je pisao o akterima promjene prostora pod utjecajem razvoja turizma u novijem razdoblju, a niz radova promatra promjene okoliša s aspekta uređenja krajobraza i arhitekture (vidi, npr. Lisac, Ivanuš, 2010.). Malo je radova posvećeno promjenama okoliša u razdoblju tranzicije i novih ekonomsko-tržišnih uvjeta. 


\section{Proučavani prostor}

Hrvatska, kao prostorno mala zemlja, posjeduje veliku raznolikost prirodno-geografskih obilježja. S obzirom na prirodna obilježja, prema krajobraznoj regionalizaciji Hrvatska je podijeljena na 16 osnovnih krajobraznih jedinica. Pridravska nizina Osijeka svrstana je u kategoriju nizinskih područja sjeverne Hrvatske (Bralić, 1999.). Kako bi se bolje razumjele mogućnosti planiranja i zakonskoga usmjeravanja u razvoju i zaštiti krajobraza, potrebno je razumjeti uzroke promjene krajobraza te osnovne procese koje taj krajobraz mijenjaju (Hesperger i Buergi, 2007.). Ovaj radi bavi se identifikacijom osnovnih procesa promjene krajobraza Pridravske nizine Osijeka.

Pridravska nizina Osijeka razmjerno je mala prostorna cjelina Istočne Hrvatske, površine $1019 \mathrm{~km}^{2}$. Izdužena je u smjeru sjeverozapad-jugoistok (uz desnu obalu Drave približno od Belišća pa da okuke Dunava kod Erduta) u dužini od gotovo 70 kilometara. Najšira je u svom srednjem dijelu (oko $20 \mathrm{~km}$ ) gdje prema jugu zalazi u blagu depresiju rijeke Vuke. Za ovu regiju ne može se reći da je prirodno jasno izdvojena (Pepeonik, 1975.), a toj tvrdnji govori u prilog i njezina potpuna otvorenost prema svim stranama svijeta. Određene zapreke čine tok Drave i podvodni, a dijelom i močvarni pojas zemljišta uz Dravu s nizvodne baranjske strane, te široki Dunav na istoku (Pepeonik, 1975.).

Osječko područje tradicionalno je usmjereno na poljoprivrednu proizvodnju radi vrlo dobrih predispozicija za tu djelatnost, ali je tijekom šezdeset godina doživjelo značajnu transformaciju u socijalnom i ekonomskom smislu, što se direktno i odrazilo na kulturnom krajobrazu. Radi lakše obrade, analize i usporedbe socioekonomskih podataka, za osnovu proučavanja uzeta je teritorijalno-administrativna cjelina Grada Osijeka. Analiza širega područja bila bi otežana radi različite metodologije vođenja statističkih podataka tijekom proteklih šezdesetak godina. Vremensko razdoblje za koje će se analizirati podaci odnosi se na najdinamičnije promjene u krajobrazu. Nakon Drugoga svjetskog rata dolazi do promjena u društveno-proizvodnim odnosima povezanim uz izgradnju socijalističkoga društva i industrijalizaciju. Sve navedeno uvjetovalo je u tom području znatne promjene u ekonomsko-socijalnoj strukturi stanovništva (Wertheimer-Baletić, 1983.). Godine 1991. uslijedile su nove promjene, od rata, prisilnih migracija stanovništva, do dubokih ekonomskih i društvenih promjena i demokratizacije društva, te prelaska s planirane na tržišnu ekonomiju.

\section{Metodološki okvir istraživanja}

Sile koje mijenjaju krajobraz obuhvaćaju gotovo svaki faktor povezan s ljudskom aktivnošću. Ovi faktori dijele se u dvije osnovne skupine - direktni i indirektni. Dok direktni djeluju na lokalnoj razini i obuhvaćaju fizičke promjene vidljivoga dijela krajobraza (zemljišnoga pokrova), indirektni su oblikovani kompleksom niza varijabli (Geist i sur., 2006.).

Zemljišni pokrov karakteriziraju fizička obilježja zemljišne površine, što uključuje tlo, vegetaciju, reljef, vode i strukture izgrađene od strane čovjeka. U metodološkom 
smislu, zemljišni pokrov i njegove promjene moguće je analizirati pomoću daljinskih istraživanja ili iz sekundarnih baza podataka. Način korištenja zemljišta često se preklapa i koristi kao sinonim za zemljišni pokrov, ali je nešto složeniji pojam i uključuje širi društveni i ekonomski kontekst unutar kojega se upravlja zemljišnim pokrovom (Lambin i sur., 2006.).

U analizi promjene krajobraza najčešće se koristi šest temeljnih indirektnih faktora: tehnološki, ekonomski, politički, institucionalni, demografski i sociokulturni, koji djeluju na regionalnoj i globalnoj razini (Geist i sur., 2006.). Postoje i posredujući faktori koji djeluju na međuodnos direktnih i indirektnih faktora. Jedni od njih su spol, etnička pripadnost ili klasa ${ }^{3}$. Postoje različiti modeli u pristupu analize promjene zemljišnoga pokrova, ovisno o vrsti izvora podataka (prostorni i neprostorni), vremenskim obilježjima modela (dinamički ili statički), prostornom obuhvatu (lokalni, regionalni ili globalni) i sl. (Verburg i sur., 2006.).

U ovom radu koristi se neprostorni, dinamički, deskriptivni induktivni model u analizi promjena okoliša u Pridravskoj nizini Osijeka, te se analizira povezanosti promjena okoliša sa socioekonomskim i demografskim faktorima u razdoblju druge polovice 20. stoljeća.

Analiza promjene okoliša bazira se na izmijenjenom modelu koji su razvili Hesperger i Buergi (2007.). Na promatranom prostoru nasumično je odabrano stotinu lokacija površine 50x50 metara, te su kroz usporedbu tih lokacija na georeferenciranim topografskim kartama Osijeka i Sombora (izdanje Geografskoga instituta JNA, reambulacija 1930., dopunjeno 1956. godine) i na satelitskoj snimci dobivenoj pomoću Google Eartha iz 2011. izdvojeni elementi i procesi fizičke promjene krajobraza. Tako je npr. lokacija 1 na topografskoj karti iz 1956. označena kategorijom šume, a ista lokacija na satelitskoj snimci iz 2011. spada u kategoriju travnjaka, te je direktni faktor promjene okoliša u ovom primjeru deforestacija. Upravo zbog takvoga načina rada promatrani model je neprostorni, jer se kao rezultat ne dobiva točan prostorni raspored izmijenjenih površina, već se analizom i zatim grupiranjem promatranih lokacija kvantificiraju direktne promjene u krajobrazu. Analizom relevantnih statističkih podataka nastojalo se evidentirati potencijalne indirektne faktore koji su uzrokovali promjene kulturnoga krajobraza Grada Osijeka u razdoblju od 1961. do 2011.godine.

\section{Promjene kulturnoga krajobraza grada 0sijeka}

Rezultati i njihova analiza, prema odabranoj metodologiji, dijele se u dva dijela. Prvi se sastoji od analize i grupiranja promatranih lokacija te time i kvantificiranjem promjena u krajobrazu, odnosno izdvajanjem direktnih faktora promjene krajobraza. Drugi dio sastoji se od analize socioekonomskih i drugih pokazatelja u svrhu

3 Tako su npr. Sader i sur. (2004.) na primjeru Maja na Yucatanu dokazali da prisutnost muške populacije statistički značajno povećava vjerojatnost deforestacije, dok je prisutnost ženske populacije smanjuje. 
prepoznavanja i izdvajanja indirektnih faktora promjene krajobraza područja Grada Osijeka.

\subsection{Analiza promjene okoliša}

Topografske karte Osijeka i Sombora (izdanje Geografskoga instituta JNA, reambulacija 1930., dopunjeno 1956. godine) skenirane su i georeferencirane pomoću već georeferenciranih topografskih karata mjerila 1:25 000. Georeferenciranje se provelo pomoću lako prepoznatljivih elemenata karte kao što su prometni čvorovi, dravske okuke i sl. (Valožić, Cvitanović, 2011.). Nakon što je karta georeferencirana, pomoću funkcije create random points u programu ArcGIS 9.2 odabrano je sto lokacija površine 50x50 metara koji su metodom vizualne interpretacije klasificirane u jednu od devet (̌̌est) glavnih kategorija zemljišnoga pokrova i korištenja zemljišta prema sustavu prilagođenom za daljinska istraživanja (Anderson i sur., 1976.). Pri tome je korišten Kartografski ključ za topografsku kartu mjerila 1:25 000 u izdanju Državne geodetske uprave (2000.). Odabranih sto kategoriziranih površina preklopljeno je i uspoređeno sa zemljišnim pokrovom i načinom korištenja zemljišta dobivenim putem aplikacije Google Earth iz svibnja 2011. godine. Analizom dobivenih sto parova lokacija dobiveni su sljedeći rezultati:

Tablica 1.

Promjene zemljišnoga pokrova odabranih lokacija Grada Osijeka od 1956. do 2011.

\begin{tabular}{|c|c|c|c|}
\hline Vrsta zemljišnoga pokrova & Stanje 1956. & Stanje 2006. & Razlika \\
\hline Obradive površine & $62 \%$ & $57.4 \%$ & $-4.6 \%$ \\
\hline Izgrađene površine & $9.2 \%$ & $22 \%$ & $+12.8 \%$ \\
\hline Šuma & $16.1 \%$ & $5.7 \%$ & $-10.4 \%$ \\
\hline Močvara & $4.6 \%$ & $3.5 \%$ & $-1.1 \%$ \\
\hline Vodene površine & $4.6 \%$ & $5.7 \%$ & $+1.1 \%$ \\
\hline Travnjaci/ugar & $3.5 \%$ & $5.7 \%$ & $+2.2 \%$ \\
\hline
\end{tabular}

Izvor: Topografske karta Osijeka i Sombora (1956.) te satelitska snimka Google Eartha, 17. svibnja 2011. godine.

Kao što je vidljivo iz tablice, najveće promjene zemljišnoga pokrova dogodile su se u kategoriji izgrađenih površina, šuma i obradivih površina. Detaljnijom analizom smjera promjena odabranih lokacija, utvrđeno je da je u 39.1\% opaženih promjena obradiva površina pretvorena u izgrađene površine, a u $17.4 \%$ promjena šuma je pretvorena u obradivu površinu, Također, u 9\% promjena šuma je pretvorena u izgrađene površine, a u istom postotku šuma je pretvorena u travnjak, te travnjaci u obradive površine. Ovom analizom obuhvaćeno je ukupno 83.5\% opaženih promjena zemljišnoga pokriva. Iz dobivenih rezultata, mogu se izdvojiti dva glavna direktna faktora fizičke promjene krajobraza Grada Osijeka, a to su urbanizacija i deforestacija. Također, opaža se veliki udio obradivih površina na promatranom području, odnosno važnost poljoprivrede i poljoprivrednih krajobraza, te relativno mali udio ugara. 
Prema ekonomskim teorijama promjene načina korištenja zemljišta, veliku ulogu u pozadini ovoga procesa igraju tzv. decision-makeri, odnosno donositelji odluka u okruženju ograničenih resursa (zemljišta) i neograničenih želja. Ekonomska analiza promjene načina korištenja zemljišta uglavnom se sastoji od pet elemenata: analize ekonomskoga ponašanja i ciljeva vlasnika zemlje, trenutne i potencijalno dostupne tehnologije proizvodnje, količine i distribucija resursa, zahtjeva tržišta, te politike (Dolman i sur., 2003.:54).

\subsection{Analiza poljoprivrednih područja}

S obzirom da je Osijek makroregionalno središte regije Slavonije i Baranje koja je tipičan poljoprivredni prostor (od čega ne odudaraju rezultati dobiveni ovim istraŽivanjem), nužno je analizirati i agrarni krajobraz, odnosno definirati sam pojam agrarnoga krajobraza. Agrarni krajobraz dio je prostora što ga čovjek iskorištava za poljoprivrednu proizvodnju. Tri su temeljna pojma koja određuju ovako definiran prostor - čovjek, poljoprivreda i priroda. Čovjek organizira poljoprivrednu proizvodnju na nekom zadanom prostoru i u njegovim prirodnim prilikama. Stoga možemo reći da je agrarni krajobraz rezultat međusobnoga djelovanja navedenih triju sastavnica. Njihovim mijenjanjem mijenja se i sam sustav a time i krajobraz koji je taj sustav predstavljao. Agrarni krajobraz stalno se mijenja pa ga zbog toga treba promatrati u kontekstu njegovoga povijesnog i prostornoga određenja (Defilippis, 2002.). Agrarni krajobraz razvija se u dva smjera, pri čemu jedan smjer znači modernizaciju i očituje se u građevinskom iskorištavanju ruralnoga prostora (gradnja cesta, širenje naselja, zračne luke, željezničke pruge, autoceste). Drugi smjer očituje se poticanjem suvremene krupne poljoprivredne proizvodnje s pretežno jednoličnim velikim površinama radi racionalnijega korištenja prostora (Defilippis, 2002.). Čak kad izostane antropogeni učinak, krajobraz doživljava promjene, i te su promjene spontane. Smatra se da je zaštita kulturnoga krajobraza čovjekova stalna težnja, kao i njegova potreba za obitavanjem u prostoru koji ima pastoralne elemente (takvi motivi bili su prisutni u slikarstvu, literaturi i sl.), a taj mit nije slika čiste prirode, divljine, već upravo kultivirane, "uređene" prirode, plodne i bogate i zbog toga čovjeku vrijedne (Marić, Grgurević, 2007.).

Suvremena poljoprivredna proizvodnja zahtijeva poljoprivredno zemljište i uvjete privređivanja koji će omogućiti optimalno iskorištavanje prirodnih resursa. Činjenica je da ti uvjeti nisu postojali na području Slavonije i Baranje, te se 1956. godine pristupilo uređenju poljoprivrednih površina komasacijom. Godine 1961. na području općine Osijek (naselja Đurđevo Polje, Josipovac, Kravice, Osijek, Tenja i Višnjevac) bilo je ukupno 2614 gazdinstava (s 3138 poljoprivrednika na gazdinstvima) s 5 306 ha poljoprivrednih površina. Ukupna površina oranica i vrtova na promatranom području iznosila je 4913 ha. Početkom 1960-ih većina općina donijela je odluku da društveni sektor preuzme sve poljoprivredno neiskorištene površine, kao i livade i pašnjake i da ih iskoristi za uzgoj određenih kultura. Kod većine je općina društveni sektor preuzeo te površine, preorao ih i zasijao, da bi nakon nekoliko godina opet vratio pod pašnjake jer je na njima ostvarivao osjetnije gubitke, budući da nije bio riješen vodozračni režim u tlu, pa su radi viška voda usjevi propadali. Od ukupnih 
površina društvenoga sektora iz toga razdoblja najviše je pripadalo kombinatima koji su od 1962. do 1977. godine povećali svoj udio s $85 \%$ na $97.9 \%$, tako da su praktično cjelokupne oranične površine bile pod vlasništvom kombinata.

Na području općine Osijek 1971. godine (naselja Ada, Aljmaš, Antunovac Tenjski, Beketinci, Bijelo Brdo, Brešce, Čepin, Čokadinci, Dalj, Divoš, Dopsin, Djurdjevo Polje, Erdut, Ernestinovo, Hrastin, Josipovac, Jovanovac, Koprivna, Laslovo, Martinci Čepinski, Osijek, Palača, Petrova Slatina, Sarvaš, Silaš, Šodolovci, Tenja, Višnjevac, Vladislavci, Vuka) bilo je ukupno 58165 aktivnih stanovnika, a od toga 11079 aktivnoga poljoprivrednog. Ukupno je na području općine zabilježeno 16\% poljoprivrednoga u ukupnom stanovništvu. Što se tiče samoga naselja Osijek, 1971. godine u njemu je zabilježeno 39365 aktivnih stanovnika, odnosno 4097 aktivnoga poljoprivrednog stanovništva (ili $4 \%$ poljoprivrednoga u ukupnom stanovništvu). Također, bilo je ukupno 66837 ha poljoprivrednih površina, odnosno 89026 katastarskih čestica, unutar 8278 poljoprivrednih domaćinstava (Panjaković, 1983.).

Ni veličina posjeda pojedinoga poljoprivrednog domaćinstva nije bila povoljna, $s$ obzirom da je 54\% svih zemljišnih posjeda bila veličine do 1 ha. Kao što podaci pokazuju, velika usitnjenost i rascjepkanost poljoprivrednih posjeda bili su uzrokom neracionalnoga korištenja zemljišta i relativnoga ekonomskog zaostajanja područja na kojima komasacija i uređenje zemljišta nije provedeno, a tako je i danas. Ipak, nakon komasacije prosječna se veličina katastarske čestice zemljišta na području općine Osijek s 0.40 ha povećala na 1.16 ha. Usporedo s komasacijom u to vrijeme (1956. - 1979.) provedene su i hidrotehničke melioracije (izgradnja kanalske mreže) (Panjaković, 1983.).

Slika 1.

Primjer veličine parcela u dijelu općine Bedekovčina (a) i Grada Osijeka (b). Iako provedena u dijelu Hrvatskog zagorja (nizinski dijelovi Krapine i Sutle), komasacija nije bila toliko uspješna te je prosječna veličina parcele u Hrvatskom zagorju 0.3 ha. Za usporedbu, prosječna veličina parcele u Gradu Osijeku veća je oko četiri puta. Prikazane karte istoga su mjerila.

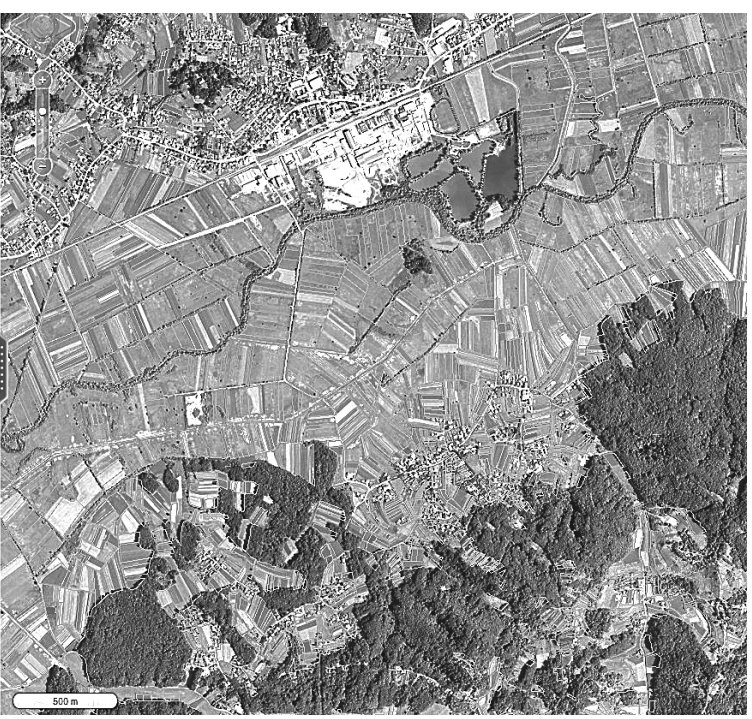

a) Bedekovčina 


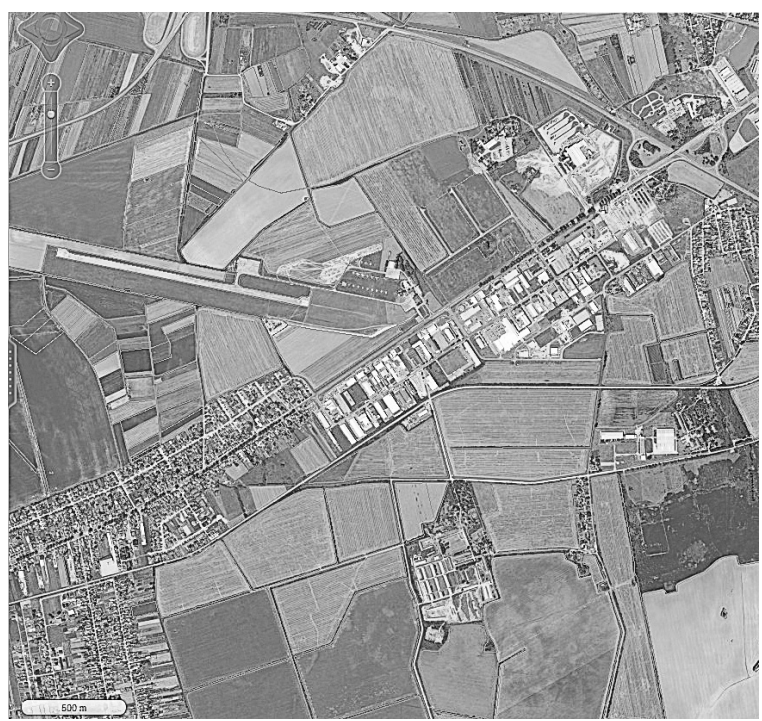

b) Osijek

Izvor: ARKOD.hr (27.7.2012.)

Tijekom 1970-ih godina dolazi do stagnacije poljoprivredne proizvodnje pri čemu su glavni problem bila nepovoljna svojstva tla, koja ograničavaju razinu iskoristivosti kapaciteta rodnosti poljoprivrednih kultura. U tom razdoblju počinje intenzivnije uređenje poljoprivrednih površina putem komasacije, odvodnje putem drenaže i arondacije. Ipak, početkom sedamdesetih godina započinje jača primjena mehanizacije u obradi zemlje, što se može vidjeti iz tablice 2. Tako je na jedan traktor 1971. godine dolazilo 34 ha obradive površine, a desetljeće kasnije na jedan traktor 8 ha, što je povećanje učinkovitosti od oko četiri puta.

Tablica 2.

Kretanje broja traktora i žitnih kombajna u općini Osijek, 1971. i 1982.

\begin{tabular}{|c|c|c|c|c|c|}
\hline \multicolumn{3}{|c|}{1971.} & \multicolumn{3}{c|}{1982.} \\
\hline $\begin{array}{c}\text { U vlasništvu } \\
\text { poljoprivrednika }\end{array}$ & $\begin{array}{c}\text { U vlasništvu } \\
\text { organiziranih } \\
\text { poljop. }\end{array}$ & Ukupno & $\begin{array}{c}\text { U vlasništvu } \\
\text { poljoprivrednika }\end{array}$ & $\begin{array}{c}\text { U vlasništvu } \\
\text { organiziranih } \\
\text { poljoprivrednika }\end{array}$ & Ukupno \\
\hline $\mathbf{5 8 0}$ & 46 & 626 & 2147 & 30 & 2177 \\
\hline
\end{tabular}

Izvor: Jakšić, S., Banić, S., 1983.

Godine 2003. na području Grada Osijeka popisano je 3870 poljoprivrednih kućanstava te 4921,46 ha raspoloživoga poljoprivrednoga zemljišta. Od toga je bilo iskorišteno 4 416,54 ha, a broj katastarskih čestica korištenoga poljoprivrednog zemljišta $6038^{4}$. Najveći broj kućanstava na poljoprivrednom zemljištu uzgajao je povrće (na

${ }^{4}$ Jedan od problema koji proizlazi iz analize statističkih podataka o korištenju zemljišta je i sama metodologija. Tako se u Popisu poljoprivrede 2003. evidentira korištenje poljoprivrednoga zemljišta koje je kroz administrativne dokumente namijenjeno za korištenje u poljoprivredi, a ne čitavo područje koje je pod poljoprivrednim kulturama. 
povrtnjacima vlastite okućnice, za vlastite potrebe) na 2550 ha, na 2241 ha kućanstva su uzgajala voće dok je 1635 ha otpadalo na oranice i vrtove. Najmanji udio kućanstava koristio je poljoprivredno zemljište kao pašnjake, odnosno rasadnike.

Bitno je još istaknuti da je od površina oranica i vrtova 2003. godine na području Grada Osijeka najviše površina bilo pod žitaricama (2 695,68 ha), odnosno uljanim sjemenjem i plodovima (800,43 ha) te krmnim biljem (205,90 ha). Ostatak najvećega dijela oraničnih površina bio je pod ugarom (1 041,92 ha). Površina zasađenih krumpirom bilo je svega 17,29 ha, šećernom repom 61,72 ha, dok duhan uopće nije bio zastupljen.

Na izgled krajobraza utječe i vrsta plodoreda. Stabilnost proizvodnje ratarskih kultura uglavnom je u uskoj vezi sa sustavom biljne proizvodnje. U ratarskoj proizvodnji Slavonije i Baranje razvijao se tzv. plodored pod nazivom "staro slavonsko tropolje". U tom plodoredu značajno mjesto imale su tri vrste kultura - žitarice, okopavine i leguminoze. Uvođenjem strojeva u poljoprivrednu proizvodnju dolazi do sve slabijega korištenja stočne sprege u obradi, pa se stoga mijenja i plodored: sve se više smanjuje udio krmnih kultura koje su služile za ishranu domaćih životinja (konja). U nizinskom dijelu Slavonije i Baranje primjenjuje se klasični sistem izmjena kultura Žitarskoga tipa, gdje se u rotaciji izmjenjuju strne žitarice i kukuruz. Ovo dvopolje proširuje se nekim industrijskim kulturama, posebno šećernom repom i uljaricama, naročito u okolici industrijskih prerađivačkih kapaciteta.

\section{Demogeografska analiza}

U strukturi gospodarstva Slavonije i Baranje u razdoblju do Drugoga svjetskog rata glavna grana bila je poljoprivreda, što je predodredilo tadašnju ekonomsku strukturu i razmještaj stanovništva. Pored velikih poljoprivrednih imanja postojala su usporedo srednja i mala seljačka gospodarstva. Nakon Drugoga svjetskog rata radikalne promjene u društveno-proizvodnim odnosima povezane uz izgradnju socijalističkoga društva i industrijalizaciju kao temeljni pravac privrednoga razvoja, uvjetovale su u tom području znatne promjene u ekonomsko-socijalnoj strukturi stanovništva (Wertheimer-Baletić, 1983.). Kao posljedica socijalne transformacije dolazi i do pojave i jačanja intenziteta ugara na tadašnjim privatnim oranicama, što bi značilo da se barem dio površina pod ugarom može smatrati "socijalnim ugarom" (Crkvenčić, 1982.).

Od 1961. godine stanovništvo naselja Osijek neprestano raste do 1991. godine (broj stanovnika u navedenom tridesetogodišnjem razdoblju povećao se 1,5 puta ili točnije za oko 33000 stanovnika), da bi 2001. godine bio zabilježen pad od 14350 stanovnika. Ovdje treba napomenuti da je 1991. naselje Osijek smanjeno izdvajanjem dijelova u istoimena naselja Podravlje i Tvrđavica, te dijelova područja u samostalna naselja Brijest i Nemetin, a povećano pripajanjem dijela područja naselja Briješće. Naselje Klisa se do 1991. godine nalazilo u sastavu Vukovarsko-srijemske županije. Što se tiče cijeloga područja Grada Osijeka, stanovništvo se najviše povećalo u popisnom razdoblju od 1961. do 1971. godine, tj. s 84652 na 109189 stanovnika, što je činilo porast od 29\%, a što se podudara s razdobljem urbano-zasnovane industri- 
jalizacije i snažne deagrarizacije i deruralizacije Slavonije i Baranje. U tom razdoblju počinje jačati urbanizacija prigradskih naselja koja u navedenom razdoblju pokazuju tendenciju povećanoga porasta broja stanovnika. Migracijski saldo za Grad Osijek najveću je vrijednost imao upravo u ovom međupopisnom razdoblju (+15 408). Migracija stanovnika u Osijeku imala je značajnu ulogu u razvoju stanovništva grada sve do 2001. godine (Jukić, Andraković, 2009.). Osijek kao samostalno naselje bilježi slično kretanje migracijskoga salda kao i administrativno područje grada. U razdoblju 1961.-1971. migracijski saldo bio je najveći i iznosio je 12992 stanovnika (Jukić, Andraković, 2009.).

Godine 1981. zabilježeno je 123944 stanovnika, a najveći broj je 1991. kada je Grad Osijek bilježio 129792 stanovnika. Godine 2001. popisano je 114616 stanovnika što je u odnosu na 1991. smanjenje kao posljedica ratnih zbivanja iz početka 1990-ih. Važno je napomenuti da je popis stanovništva 2001. rađen po principu prisutnoga (de facto) stanovništva, dok su popisi od 1971. do 1991. rađeni po principu stalnoga (de iure) stanovništva. Stoga je i to jedan od razloga zbog kojega je zabilježen veći pad broja stanovnika u međupopisnom periodu 1991. - 2001. Prema privremenim podacima popisa stanovništva za 2011. godinu u Gradu Osijek zabilježeno je 107 485 stanovnika, pri čemu samo naselje Osijek ima 83496 stanovnika.

Jedan od uzroka takvom kretanju stanovništva na području Osijeka, a naročito od 1961. do 1981. bilo je već spomenuto smanjivanje seoskoga i povećanje stanovništva u gradovima, odnosno općinskim središtima, što je dovelo do niza problema. Ti se problemi mogu svrstati u dvije skupine: smanjivanje poljoprivrednoga stanovništva i poljoprivredne proizvodnje na selu, te neplanski razvoj gradova, općinskih i industrijskih središta (Panjaković, 1983.).

Tablica 3.

Broj stanovnika Grada Osijeka od 1961. do 2011.

\begin{tabular}{|c|c|c|c|c|c|c|}
\hline Naselje & $\mathbf{1 9 6 1 .}$ & $\mathbf{1 9 7 1 .}$ & $\mathbf{1 9 8 1 .}$ & $\mathbf{1 9 9 1 .}$ & $\mathbf{2 0 0 1 .}$ & 2011. \\
\hline Brijest & 0 & 382 & 608 & 1.029 & 1.248 & 1.183 \\
\hline Briješće & 707 & 449 & 649 & 953 & 1.382 & 1.327 \\
\hline Josipovac & 2.534 & 2.805 & 3.233 & 4.043 & 4.395 & 4.119 \\
\hline Klisa & 331 & 308 & 346 & 419 & 463 & 324 \\
\hline Nemetin & 0 & 483 & 477 & 400 & 177 & 133 \\
\hline Osijek & 71.782 & 92.603 & 103.026 & 104.761 & 90.411 & 83.496 \\
\hline Podravlje & 715 & 991 & 670 & 467 & 358 & 345 \\
\hline Sarvaš & 1.488 & 1.558 & 1.750 & 1.839 & 1.539 & 1.875 \\
\hline Tenja & 4.578 & 5.299 & 6.515 & 7.663 & 6.747 & 7.401 \\
\hline Tvrđavica & 628 & 589 & 601 & 1.014 & 750 & 570 \\
\hline Višnjevac & 1.889 & 3.722 & 6.069 & 7.204 & 7.146 & 6.712 \\
\hline UKUPN0 & 84.652 & 109.189 & 123.944 & 129.792 & 114.616 & 107.485 \\
\hline
\end{tabular}

Izvor: Popis stanovništva 1857. -2001., DZS, Zagreb 


\subsection{Analiza stanovništva prema ekonomskoj strukturi}

U radu su analizirane samo one djelatnosti u kojima je u promatranim godinama bilo najviše zaposlenih. U svim promatranim razdobljima to su industrija, poljoprivreda, promet, građevinarstvo i trgovina, dok su druge djelatnosti zastupljene samo u pojedinim godinama. Prema podacima popisa stanovništva od 1961. godine u općini Osijek od ukupnoga broja aktivnoga stanovništva (82 126) najviše je aktivnih bilo u djelatnosti industrije (13 346), odnosno poljoprivrede (3 559), te trgovine i ugostiteljstva (3 182). Slijedile su djelatnosti kao što su zanatstvo, promet, te zdravstvena i socijalna djelatnost.

Popis stanovništva 1971. godine za područje tadašnje općine Osijek pokazao je da je situacija bila približno ista, kao i desetak godina ranije. Aktivnih djelatnih stanovnika ipak je bilo manje nego 1961., tj. 58 165. Kao i tada, najviše aktivnoga stanovništva na području općine bilo je zaposleno u industriji (16 641), poljoprivredi i ribarstvu (10 282), te trgovini i ugostiteljstvu (5 291). Ipak, iste godine i kulturna i socijalna djelatnost dobivaju na značenju jer je u njima bio zaposlen 5231 aktivni stanovnik. Slijedile su djelatnosti kao što su zanatstvo, promet i građevinarstvo.

Dvadeset godina kasnije, točnije 1991., na području općine Osijek bilo je 62596 aktivnih djelatnih stanovnika, od čega najviše u djelatnosti industrije (20 244). U poljoprivredi je radilo 4370 zaposlenih.

S obzirom da je tijekom 1990-ih godina uslijedila privatizacija, restrukturiranje i tranzicija hrvatskoga gospodarstva, uključujući i osječko, u gospodarskoj strukturi stanovništva dogodile su se značajne promjene: Na području Grada Osijeka 2001. godine bilo je ukupno 39248 zaposlenih, što znači da se broj zaposlenih znatno smanjio u odnosu na prethodna promatrana razdoblja. Broj zaposlenih u industriji također je smanjen u odnosu na ranije godine, točnije za više od 50\% (6 596 zaposlenih). U isto vrijeme povećan je broj zaposlenih u trgovini (6 197) pa je ona uz industriju postala najznačajnija gospodarska djelatnost Grada Osijeka (slika 2). Od ostalih djelatnosti, najviše je zaposlenih bilo u javnoj upravi i obrani (4 290), zdravstvenoj zaštiti i socijalnoj skrbi (2 979), te obrazovanju (2 939) i djelatnosti prijevoza, skladištenja i veza (2 604). U poljoprivredi, šumarstvu i lovu bilo je zaposleno 1086 osoba.

Smanjivanje aktivnoga poljoprivrednog stanovništva stvorilo je sljedeće probleme na selu: smanjivanje obradivih površina i napuštanje privrednih i stambenih objekata, pomanjkanje radne snage na selu, te ekstenziviranje dijela poljoprivredne proizvodnje i opadanje tržišnih viškova sa sela (Panjaković, 1983.). Sve navedeno ujedno govori i o strukturnim promjenama koje su nastale na ovom prostoru a išle su u pravcu jačanja sekundarnih i tercijarnih djelatnosti (Panjaković, 1983.). Tradicionalni seljak nestaje a time i njegova funkcija "vrtlara prirode", kreatora raznolikoga, razigranoga agrarnog krajobraza. Agrarni krajobraz uzmiče prepuštajući svoje površine izvornoj samonikloj vegetaciji (Defilippis, 2002.). 
Slika 2.

Broj zaposlenih na području općine/grada Osijeka od 1961. do 2010.

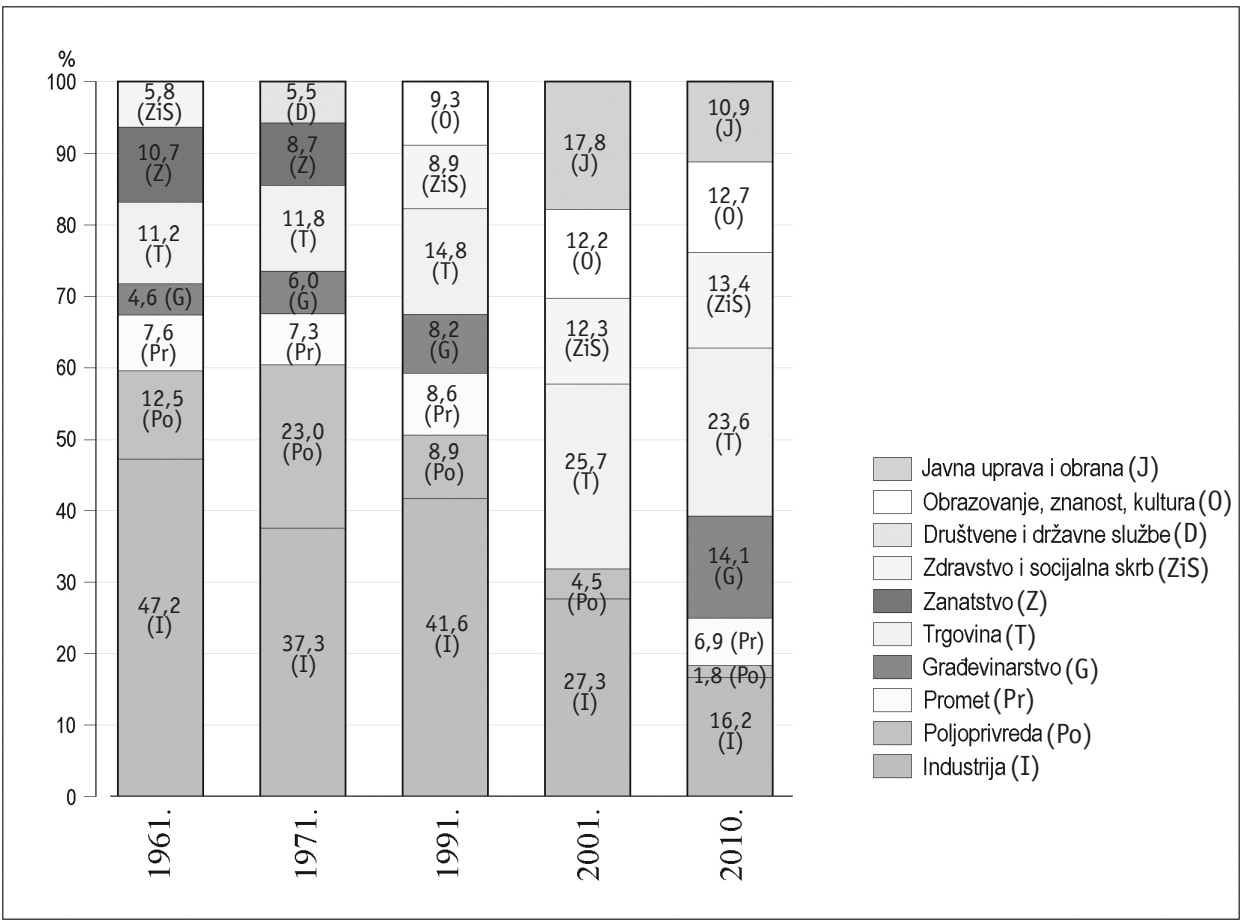

Izvor: Popisi stanovništva 1961., 1971., 1991, 2001., Statistička izvješća 2011.

\section{Zaključak}

Na području Pridravske nizine Osijeka došlo je do značajnih promjena u kulturnom krajobrazu. Deforestacijom i urbanizacijom smanjena je ukupna površina pod šumama, a elementi urbanoga krajobraza zamijenili su poljoprivredne u gotovo polovici promatranih lokaliteta. Tijekom pedesetogodišnjega razdoblja na analiziranom prostoru došlo je do smanjenja obradivih površina zbog napuštanja poljoprivrede kao djelatnosti i razvoja drugih gospodarskih grana. Pad agrarnih površina u Hrvatskoj rezultat je ranije pokrenutih procesa deagrarizacije i u novije vrijeme posljedica Domovinskoga rata, te demografskoga pražnjenja ratom zahvaćenih područja.

Međutim, smanjenje poljoprivrednih površina manje je od očekivanoga. Kada se govori o urbanizaciji okolice Osijeka 1960-ih i 1970-ih godina, mora se imati na umu da je to tradicionalno agrarni prostor u kojem zbog sporijega razvoja sekundarnih i tercijarnih djelatnosti nije došlo do dinamičnijega socijalnog prestrukturiranja agrarnoga stanovništva. U posljednjim desetljećima 20. stoljeća došlo je ipak do izraženije društveno-gospodarske transformacije okolice grada i šire regije unutar koje se Osijek razvio, no važnost poljoprivrede u krajobrazu je ostala, prvenstveno uslijed intenzifikacije proizvodnje, odnosno ekonomskih i tehnoloških faktora. 
Ekonomski i tehnološki faktori igraju značajnu ulogu u transformaciji kulturnoga krajobraza. Procesi socioekonomskoga i političkoga restrukturiranja mijenjali su izgled krajobraza planskim aktivnostima poput melioracije, komasacije i arondacije poljoprivrednoga zemljišta, pri čemu se prosječna veličina parcele u promatranom razdoblju više nego udvostručila. Uvođenjem mehanizacije i privođenjem posjeda kombinatima u razdoblju socijalizma, povećala se produktivnost, ali se izmijenila tradicionalna struktura i izgled krajobraza.

Pad industrijske proizvodnje i broja zaposlenih u industriji također je evidentan. Procesi deindustrijalizacije i tercijarizacije govore u prilog tezi da društvo ulazi u postindustrijsko doba. Unatoč očuvanju važnosti poljoprivredne proizvodnje, uz procese demografskoga starenja te pada ukupnoga broja stanovništva, pitanje je hoće li se opaženi trendovi očuvati i nastaviti ili će potencijalne promjene i nove prilagodbe u svjetlu pristupa Hrvatske Europskoj Uniji igrati ulogu u nekim novim promjenama okoliša kako Pridravske nizine Osijeka, tako i širega društva, prostora i vremena.

\section{Literatura}

1. Anderson, James R.; Hardy, Ernest E.; Roach, John T.; Witmer, Richard E. (1976). A Land Use And Land Cover Classification System For Use With Remote Sensor Data. Geological Survey, 964: 1-41.

2. Andlar, G.; Aničić, B.; Pereković, P.; Rechner Dika I.; Hrdalo I. (2011). Kulturni krajobraz i legislativa - stanje u Hrvatskoj. Društvena istraživanja, 20 (3): 813835.

3. Bralić, I. (1999). Krajobrazno diferenciranje i vrednovanje s obzirom na prirodna obilježja, u: Sadržajna i metodska podloga krajobrazne osnove Hrvatske. Zagreb: Ministarstvo prostornog uređenja, graditeljstva i stanovanja/Agronomski fakultet Sveučilišta u Zagrebu.

4. Claval, P. (2008). The idea of landscape. Pregledano rujan, 2008. (http://tercud. ulusofona.pt/PECSRL/IDENTERRA Idea of landscape.pdf).

5. Crang, M. (1998). Cultural Geography. Oxford: Routlege.

6. Crkvenčić, I. (1982). Pojava ugara i neobrađenih oranica i promjene brojnosti stanovnika SR Hrvatske u posljednjih dvadeset godina. Geografski glasnik, 44: 3-22.

7. Crkvenčić, I. (1983). Regionalne razlike i promjene površina kategorija iskorištavanja poljoprivrednog zemljišta SR Hrvatske. Geografski glasnik, 45: 55-73.

8. Defilippis, J. (2002). Razvitak hrvatskog agrarnog krajolika, u: Štambuk Maja; Rogić Ivan i Mišetić Anka (Ur.). Prostor iza - Kako modernizacija mijenja hrvatsko selo. Zagreb: Institut društvenih znanosti Ivo Pilar.

9. Dolman, A. J.; Verhagen, A. and Rovers C. A. (2003). Global environmental change and land use. Dordrecht: Kluwer Academic Publishers.

10. Dumbović Bilušić, B. i Obad Šćitaroci M. (2007). Kulturni krajolici u Hrvatskoj - identifikacija i stanje zaštite. Prostor, 15, 2 (34): 261-271.

11. Farina, A. (2000): The Cultural Landscape as a Model for the Integration of Ecology and Economics. BioScience, 50 (4): 313-320. 
12. Fuerst-Bjeliš, B.; Lozić, S.; Cvitanović, M.; Durbešić, A. (2011). Promjene okoliša središnjeg dijela Dalmatinske zagore od 18. stoljeća, u: Matas, M. i Faričić, J. (Ur.). Zagora između stočarsko-ratarske tradicije te procesa litoralizacije $i$ globalizacije. Sveučilište u Zadru, Kulturni sabor Zagore i ogranak Matice Hrvatske Split, Zadar i Split.

13. Fuerst-Bjeliš, B. i Zupanc, I. (2007). New 18th Century Venetian Border in Croatia and its Spatial and Demographic Implications. Hrvatski geografski glasnik, 69 (2): 41-52.

14. Geist, H.; McConnel, W.; Lambin, E. F.; Moran, E.; Alved, D.; Rudel, T. (2006). Causes and Trajectories of Land Use/Cover Change, in: Lambin, E. F. and Geist , H. J. (Eds.). Land-Use and Land-Cover Change. Berlin: Springer.

15. Holt-Jensen, A. and Raagmaa, G. (2010). Restitution of agricultural land in Estonia: Consequences for landscape development and production. Norsk Geografisk Tidsskrift, 64 (3): 129-141.

16. Jakšić, S. i Banić, S. (1983). Razvoj poljoprivrede i organiziranost sela Slavonskobaranjske regije, u: Sto godina poljoprivrednog zadrugarstva Slavonije i Baranje (1883.-1983.). Osijek-Lovas: Zadružni savez Slavonije i Baranje.

17. Janeković, G. (1970). Pedološke karakteristike Slavonije i Baranje, u: Radauš, V. (Ur.). Zbornik radova prvog znastvenog sabora Slavonije i Baranje. Osijek 17-19.5.1970.

18. Jukić, M. i Andraković, V. (2009). Dinamika stanovništva grada Osijeka od 1857. do 2011.godine. Anali Zavoda za znanstveni i umjetnički rad u Osijeku, 25: 23-46.

19. Krištofić, B. (2010). Krajolik s kapitalom u pozadini: O akterima promjena u ruralnom prostoru na primjeru općine Lovinac. Sociologija i prostor, 48 (2), 273 -300 .

20. Lambin, E. F.; Geist, H. and Rindfuss, R. R. (2006). Local Processes with Global Impacts, u: Lambin, E.F. and Geist, H. J. (Eds.). Land-Use and Land-Cover Change. Berlin: Springer.

21. Lisac, R. i Ivanuš, M. (2010). Krajobrazni uzorci planinskih naselja Sjevernoga Velebita. Prostor, 18 (2): 424-437.

22. Marić, M. i Grgurević, O. (2007). Krajobraz - suvremena europska kretanja, slovenski model i iskustva, stanje u Hrvatskoj. Prostor, 15, 2 (34): 273-281.

23. McKibben, B. (1989). The end of Nature. New York: Random House.

24. Melluma, A. (1994). Metamorphoses of Latvian landscapes during fifty years of Soviet rule. GeoJorunal, 33 (1): 55-62.

25. Panjaković, M. (1983). Uloga i značenje komasacija u razvoju poljoprivrede Slavonije i Baranje, u: Treći znanstveni sabor Slavonije i Baranje (svezak 1). Vukovar 29-31.10.1980. Osijek: Jugoslavenska akademija znanosti i umjetnosti, Zavod za znanstveni rad.

26. Panjaković, M (1983). Utjecaj osnovnih funkcija na depopulaciju seoskih naselja u Slavoniji i Baranji, u: Treci znanstveni sabor Slavonije i Baranje (svezak 1). Vukovar 29-31.10.1980. Osijek: Jugoslavenska akademija znanosti i umjetnosti, Zavod za znanstveni rad.

27. Pepeonik, Z. (1975). Pridravska nizina Osijeka, u: Crkvenčić, I. (Ur.). Geografija SR Hrvatske, Istočna Hrvatska (knjiga 3). Zagreb: Institut za geografiju Sveučilišta u Zagrebu, Školska knjiga. 
28. Plumwood, V. (2006). The Concept of a Cultural Landscape: Nature, Culture and Agency of the Land. Ethics \& the Environment, 11 (3): 115-150.

29. Ramankutty, N.; Foley, J. A. and Olejniczak, N. J. (2002). People on the land: Changes in global population and croplands during the 20th century. Ambio, 31 (3): 251-257.

30. Sader, A.; Chowdhury, R. R.; Schneider, L. C.; Turner, B. L. II (2004). Forest change and human driving forces in Central America, in: Gutman, G.; Janetos, A. C.; Justice, C. O.; Moran, E. F.; Mustard, J. F.; Rindfuss, R. R.; Skole, D.; Turner, B. L. II; Cochrane B. A. (Eds.). Land change science: Observing, monitoring and understanding trajectories of change on the Earth's surface (Remote Sensing and Digital Image Processing Series). Dordrecht/Boston/London: Kluwer Academic.

31. Simmons, I. (2010). Globalna povijest okoliša. Zagreb: Disput.

32. Skole, D. L. (1994). Data on Global Land Cover Change: Acquisition, Assessment and Analysis, in: Meyer, W. B. and Turner, B. L. II (Eds.). Changes in Land Use and Land Cover: A Global Perspective. Cambridge: Cambridge University Press.

33. Valožić, L. and Cvitanović, M. (2011). Mapping the Forest Change: Using Landsat Imagery in Forest Transition Analysis within the Medvednica Protected Area. Hrvatski geografski glasnik, 73 (1): 245-255.

34. Verburg, H.; Rounsevell, M. D. A. and Veldkamp, A. (2006). Scenario-based studies of future land use in Europe. Agric Ecosyst Environ, 114: 1-6.

35. Wertheimer-Baletić, A. (1983). Demografski razvoj Slavonije i Baranje, u: Treći znanstveni sabor Slavonije i Baranje (svezak 1). Vukovar 29-31.10.1980. Osijek: Jugoslavenska akademija znanosti i umjetnosti, Zavod za znanstveni rad.

\section{Izvori:}

ARKOD.hr (27.7.2012.9)

Kartografski ključ za topografsku kartu mjerila 1:25 000, verzija 1.5., Republika Hrvatska, Državna geodetska uprava, Zagreb 2000.

Stanovništvo Hrvatske od 1857-2001., CD, Državni zavod za statistiku.

Popis poljoprivrede 1960., Osnovni podaci individualnih gazdinstava po naseljima, Knjiga I, Savezni zavod za statistiku, SFRJ, Beograd, 1964.

Popis stanovništva i stanova 1971., Stanovništvo, Poljoprivredno stanovništvo, Rezultati po naseljima i opštinama, Knjiga XI, Savezni zavod za statistiku, SFRJ, Beograd, 1973.

Popis poljoprivrede 2003., www.dzs.hr. (1.5.2011.)

Popis stanovništva 1961., Knjiga XIV, Aktivnost i delatnost, rezultati za neselja, Beograd, 1965.

Popis stanovništva i stanova 1971., Stanovništvo i delatnost, Knjiga X, rezultati po neseljima i opštinama, Beograd, 1974.

Aktivno stanovništvo u zemlji koje obavlja zanimanje prema području djelatnosti po naseljima, Popis 1991.

Zakon o zaštiti okoliša, 2007. 
Jelena Lončar

Faculty of Science, Department of Geography, University of Zagreb, Croatia

e-mail: jloncar@geog.pmf.hr

Marin Cvitanović

Faculty of Science, Department of Geography, University of Zagreb, Croatia

e-mail:mcvitan@geog.pmf.hr

\title{
Post-socialism and Environment: Change of Cultural Landscape in the Drava Valley and Osijek in the Last 50 Years
}

\begin{abstract}
Socio-economic and social changes affect the environment. The changing structure of population (work and education) and changing economic conditions of production indirectly change the environment. This can be seen in the disappearance of traditional land cultivation, the intensification of agriculture, spreading of urban way of life into rural areas or, on the other hand, certain areas are abandoned and left to secondary succession. Consequently, landscape loses its identity and is left to inadequate improvement or degradation. The EU, however, insists on the efficient introduction and implementation of measures to protect the landscape. In the recent years a lot of interdisciplinary reasearch has focused on the analysis of the changing cultural landscapes. In this work we examine the changes in the Drava valley and the town of Osijek in the period between 1961 and 2011 which also includes the following settlements: Tenja, Brijest, Briješće, Višnjevac, Josipovac, Tvrđavica, Sarvaš, Klisa, Nemetin and Podravlje. Methods of remote research and statistical data processing were used. The town of Osijek went through significant social and economic changes in the observed period. They directly and indirectly affected the state of land and its usage and thus the cultural landscape. Processes of the physical alteration of the landscape were noted as well as socio-economic, demographic and other elements which caused those changes. The obtained results show the significance and extent of the changes.
\end{abstract}

Key words: the Drava valley, Osijek, cultural landscape, agrarian landscape, transition period. 